\section{1. 心筋虚血の程度と拡がりに関する実験的研究} (九州大 循環器内科) 菊池裕 友池 仁掦

目的：実験的急性冠閉塞（CAO）に際し，心筋血流量 $(\mathrm{MBF})$ ，心電図， ${ }^{99 \mathrm{~m} \mathrm{~T}} \mathrm{~T}-$ - ピ燐酸 (99m Tc-PP) の集積, 心筋 C.PK, 組織所見学検索し, 心筋虚血の积度と拡が りの栖洒に果たす役割を検討した。

方法：犬右冠状動脈前下行枝を結禁し急性心肪虚血発 作成. MBF は放射性標識微粒子法，または ${ }^{14} \mathrm{C}$ ーアンチ ピリン $\left.{ }^{14} \mathrm{C}-\mathrm{AP}\right)$ によるオートラジオグラフィー (ARG) で，心筋 CPK は Rosalki の変法で測定. 心電図は心表 面，または前胸壁で記録. ${ }^{99 m} \mathrm{Tc}-\mathrm{PP}$ は湃殺前90分に注 入.

結果：1) CAO 後の MBF 变化; 覚醒犬で虚血中心部 の心外膜㑡 $\mathrm{MBF}$ は CAO 15 分後 $0.1 \mathrm{ml} / \mathrm{min} \cdot \mathrm{g}$ 加 524 時 間後 $0.25 \mathrm{ml} / \mathrm{min} \cdot \mathrm{g}$ と增加 $(P<0.01)$ ，乙かし心内膜側の それは不変。また別の麻酔開胸犬実跧で心内・外膜側の MBF は CAO30分後にそれぞれ 0.19, $0.14 \mathrm{ml} / \mathrm{min} \cdot \mathrm{g}, 3$ 週後0.51, $0.67 \mathrm{ml} / \mathrm{min} \cdot \mathrm{g}$ と共に有意に增加した $(\mathrm{P}<0.001)$.

2) 心筋血流量と心電図; MBF と心表面心電図のST

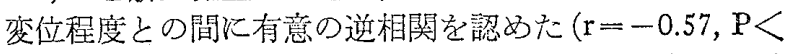
0.001)。乙かし，高度の虚血状態にもかかわらず，STが 上昇しない場合や一旦上年した ST が MBF の変化と無 関係に急速に低下寸る場合も岁る。， 又，覚醒下 CAO 30 分後の前胸壁36点の ST 上昇度と, CAO 15分後の $\mathrm{MBF}$ $0.30 \mathrm{ml} / \mathrm{min} \cdot \mathrm{g}$ 以下の領域の拡がりとの間に有意の相関 を認めなかった。

3） 99m'Tc PP の集積と MBF，組織像; $99 \mathrm{~m} \mathrm{mc}-\mathrm{PP}$ は 急性心筋梗塞辺縁部に主として集積し, その程度はCAO, 2，7，28日後それぞれ正常域の35，21，4倍であった。 micro ARGで99m Tcの分布を定量し, 梗塞辺縁部には正 常部，境界部正常側，梗塞中心部に比し約 5 倍存在して いることを認めた。 $99 \mathrm{~m} \mathrm{Tc}-\mathrm{PP}$ 集積を示す領域, ${ }^{14} \mathrm{C}-\mathrm{AP}$ の ARG で灌流低下定示す領域，脱水素酵素活性低下を 示す領域の間にはとれぞれ高い正相関を認めた。CAO 48時間後の心筋 CPK が正常部の30４0\%低下した領域 に ${ }^{99 \mathrm{~m} T c-P P}$ の最も高い集積を認わた。

4)心筋 CPK 活性と MBF ; CAO 48時間後の心筋 CPK と $\mathrm{MBF}$ との間に有意の正相関を認めた。

結論：1) CAO による MBF 低下は時間と共にある程 度回復し心外膜側で著しい。

2) MBF 低下と心表面心電図 ST 上昇度，心筋CPKの 減少度との間に有意の相関を認める.

3） $99 \mathrm{~m} \mathrm{Tc}-\mathrm{PP}$ は念性心筋梗塞部辺縁に著明な集程を 認める。

2. 急性心筋梗塞における血中心筋ミオシン軽鎖 $(\mathbf{I I})$ の 測定一その流出パターンの実験的, 臨床的検討

（菄京大 第三内科）矢崎 義雄 永井 良三

心筋固有の収縮蛋白でめるミオシンの，最小のサブュ ニットである軽鎖 (light chain) II (分子量 2 万)の radioimmunoassay 法を開発し，虚血により心筋から血中心 流出する量学測定，その経時的変化と梗塞の大きさとの 関連を実験的及び臨床的に検討し，従来の心筋梗塞の生 化学的診断法に比して，その特異性と感度がすぐれてい
ることを示した。

(方法)ヒト及びイヌの心管よりミオシンを抽出, サブ ニニットである軽鎖を分画，更に分子量の小さい方の連 鎖II 単離し，その抗体を作成してその radioimmunoassay 法をヒト及びイヌで確立した。 CPK・MB isozyme も電気泳動営光法にて测定した。実験的心筋梗塞は，雄 成犬 $(10 \mathrm{~kg}) 25$ 匹を麻酔下で開胸，冠状動脈前下降枝学 結禁して作成，15分後に閉胸し，経時的に採血して軽鎖 II 値を測定した。

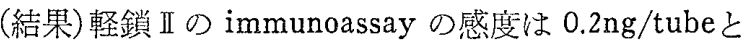
非常に高く，実験的心筋梗塞では，開胸前の血中連鎖 I 值は 0〜20ng/ml，開胸後の值は 5〜35ng/ml でわずか な上昇をみるのみであった，骨格筋ミオシン軽鎖との交 㞋反応は22\%であった。血中への流出の時間的経過をみ ると，結禁後 4 時間ですでにその值は有意の上昇定示し，

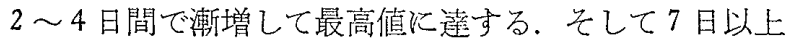
の長期にるたって有意の高值を保持する特徴むるパター ンを呈した。 最高值は 60〜320ng/mI で, 最高值と流出 量はよく相関し，昰た流出量と病理学的方法で測定した 心筋梗塞の大きさともよく一致していた $(\mathrm{r}=0.72)$. 臨床 例に於ても，実験的心筋梗塞に注注同じ変動の経過をと り，酵素值が注ぼ正常に庆った発作 1 週間後でも有意の 高值を示していた。

（考案）軽鎖 I は棈造蛋白の一部であるにもかかわら ず細胞中にフリーのプールがあるため，CPK 等の膜透 過性允進によって流出する細胞質酵素と同じく，虚血後 早期に血中に出現し，乙か子心筋細胞構造破壊の進展に 伴ってさらに增加し，比較的長期間にわたって血中で高 值を保ら，往来の测定でみられなかった特異的なパタ一 ンを示した。即ち，臨床的には早期診断に用いられると 同時に，発作後 1 週間以上経過した症例で む retrospective に診断できるニニークな診断法の開発となってい る。その特異性と測定の感度は $\mathrm{CPK}, \mathrm{MB}$ よりややす ぐれ，梗塞の大きさとの相関には有意の差はなかったが， 本测定法抙多数の試料觉測定出来る利点もある.

\section{3. 心筋虚血の評価における心電図 $\mathbf{S T}$ 偏位の意義と その限界}

$$
\text { （神戸大 第一内科）水谷 哲郎 }
$$

穔山光宕

近年 Maroko らにより，心表面心電図に晾けるST部 上年之心筋内 CPK 酵素含量, 組織血流量, 更に組織学 的変化などとの間に密接な関連性の存在する事実が指摘 され，以後Epicardial Mapping 法及び Precordial Mapping 法として，ST 部上䒜は実験的並びに臨床的に急性 心筋梗塞の拡がり, 重症度の分類, 薬物効界の判定などに 有用されるにいたった。乙かし，Maroko ら自身によっ ても指摘されている如く，本法の適応とその解橎には幾 多の問題点を有する，我々は心䒾面及び心筋内心電図法 を用い，冠動脈結禁及び冠動脈の段階的狭窄時のST 部 偏位の出現を钼察するとともに，ST 部偏位出現時の冠 血行動態並びに心筋代謝变動を明らかにすることにより，

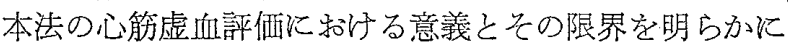
するべく，以下の荚験を行った。

実験には雑種成犬を用い，麻酷開胸下に左冠動脈前下 行枝灌流域に心表面及び心飭内多極針電極妿挿入し，局 
所単極誘導心電図を記録した，同時に前下行枝に和ける 冠血流量，冠灌流圧，交文熱電対法により局所心筋血流 量, 医用質量分析器により心筋酵素及び炭酸ガス張力の 測定を伊せ実施した。

心表面心電図に和けるST 部上昇は，冠灌流量の90\%， 冠灌流圧の75\%以上の低下時に，また局所心筋流量上り みると，心筋外層の血流量が50\%以上の減少時には，心 表面心霍図上で57\%に，内膜側血流の50\%以上の減少時 には50\%に諗められた。 しかし局所血流量の75\%以上の 著明な減少にもかかわらず，ST上昇の認められぬ側も あり，局所流量变化之心表面心電図の ST 上昇との間に かなりの不一致がみられた．局所心筋内ガス変動との関 連性をみると，心表面心電図での ST 上年は，心筋内外

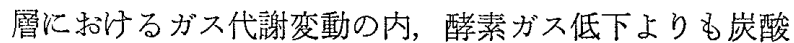
ガス上昇との間により強い関連を示する，不一致を示す 例も多く, 同時に測定した心筋内心電図上での変化に比 して，局所血行動態及び代謿変動を反映しがたいるのと の結諭学得た。

更に，冠動脈結柴実験にて，虚血中心部，辺縁部，正

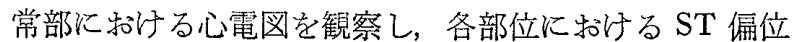
の变動様式の差異を检討するとともに，また心筋内，心 表面及び胸壁誘導の三者間に叔计るST 偏位の出現につ き述べる予定である。

\section{4. 体表面電位図による心筋梗塞の部位と大きさの診断 一心臟カテーテル， ${ }^{201} \mathbf{T} 1$ 心筋シンチグラフィー所 見との対比}

\section{（名古屋大 第一内科）林博史 渡辺 佳彦}

目的：心筋梗塞の体表面電位図 (map) を，冠動脈，右 室造影所見, ${ }^{201} \mathrm{Tl}$ 心筋シンチグラフィー (MSG) 等と対 比して虚血又は梗塞に陷った心筋のより正確な部位及び 大きさの診断を試みた。

対象：急性梗塞30例，陳旧性梗塞122例，計152例（平 均年令58才）を対象とした，冠動脈及び左室造影は68例 に， ${ }^{201}$ TI MSG は43例に施行した，対照群として，健康 成人40名の mapを用いた。

方法：体表面上 85 点から単極誘導心電圈を記録し, $3 \mathrm{msec}$ 每の QRS 群 (QRS map), S 波の谷加ら 60msec 後のST 部分の map (ST map)を作成した.

また，40msec 以上の異常 $\mathrm{Q}$ 波を示す領域 $\left(\mathrm{Q}_{40}\right.$ area), 体表上各誘導点每に心室脱分極期を通じて，その点が示 与正の最大電位を求め, その等電位線の分有図 (Peak

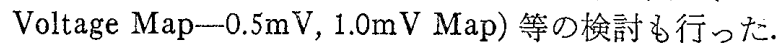
急性梗塞においては，発症十数時間より，約 3 週間に亘

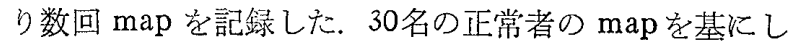
て, “平均” map 求め, こ机を梗塞例の map 加差 引き，10msec 毎に “差” の map (Subtraction Map) を

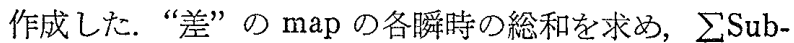
traction Map とした.

結果: [A] 急性梗塞，1） $Q_{40}$ area: $Q_{40}$ area は，梗塞部 位により特徴的な分布を示し，その拡りは軽症例では発 症 1 週間以内に比較的急速に減少し, 重症例ではその減 少の速度が遅延した，2) Peak Voltage Map：0.5 又は $1.0 \mathrm{mV}$ 以上を示す領域は，正常に比して著しくその大き さを減じた。梗塞発症後 2 週間までは，この領域は徐々
に正常方向へ拡大したが，3〜4週間後からの変化は僅 少であった. 3) ST Map と $\mathrm{Q}_{40}$ area: ST 高電位領域は, $\mathrm{Q}_{40}$ area とは比較的大きなずれがみられる例が多く，そ の大きさの経時的な減少の速度は， $\mathrm{Q}_{40}$ area のそれより 急速であった。

[B] 陳旧性梗塞. 1) Subtraction Map と左室造影所見: “差”の map に和活負領域の位置, 拡がり，その負電 位の強さは，左室収縮異常の部位，拡がり及び程度をよ く反映した. 2) $\mathrm{Q}_{40}$ area の拡がりのパターンにより，病 変冠動脈の数, 病変部位 (中权又は末梢部), 艺の程度等 がある程度推測できた。 3) $\mathrm{Q}_{40}$ area と ${ }^{201} \mathrm{Tl} \mathrm{MSG}: \mathrm{Q}_{40}$ area ${ }^{201} \mathrm{Tl}$ 提取率性逆相関した $(\mathrm{r}=-0.71, \mathrm{P}<0.01)$. $\sum$ Subtraction Map での異常負領域と ${ }^{201} \mathrm{~T} l$ 摄取率の低 下部位はよく一致した。 4) ST Map: ST 高電位領域は, 高度の左室収縮畾常の部位と拡がりをよく反映した。 5)前壁中隔，側壁梗塞の駆出率は， Q 40 area と逆相関し， $\sum R$ と正相関した。

結論：体表面電位図により，梗塞部位，拡がり，左室 収縮異常等が高い信頼度が診断できると考えられた。

\section{201 Thallium 負荷心筋 imaging による心筋虚血の 評価}

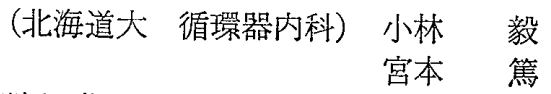

心筋局所の灌流異常あるいは，心筋虚血の存在を ${ }^{201}$ Thallium $(\mathrm{Tl})$ 心觔 imaging 法などの核医学的方法を 応用して評価した。

I ): 基礎的検討. 方法; Pentobarbital 麻酔イヌを用 い人工換気下に開胸し，冠動脈枝の結禁あるいは結禁解 除後に速やが ${ }^{201} \mathrm{~T}$ 学静注し，ついで心葴を摘出した。 その横断標本について SEARL Pho/Gamma LFOV に より ${ }^{201} \mathrm{Tl}$ image 心筋を作製し，冠血流と ${ }^{201 \mathrm{~T}}$ 摄取と の関係をみた，成績；冠動脈枝結禁では，同枝の灌流支 配域で低灌流を反映し，局所的欠損像が得られた。 結禁解除臬後の ${ }^{201} \mathrm{TI}$ 静注では，反応性充血を反映する 局所的な ${ }^{201 \mathrm{~T} 1}$ 放射活性の著しい蓄積增加の像が得られ た. 以上から ${ }^{201} \mathrm{TI}$ は心藏組織に速やかに摄取され，心 筋局所の灌流变化を反映する。したがって ${ }^{201} \mathrm{~T} 1$ 心筋 imaging 法は灌流状態の視覚的な指栖として利用しらる。

II)：臨床的検討，方法；冠動脈疾患が疑わ水選択的 冠動脈造影を施行した症例を対象に ${ }^{201} \mathrm{Tl} 3 \mathrm{mCi}$ を静注 し, 安静時, 運動負荷による狭心発作誘発時点での ${ }^{201} \mathrm{Tl}$ 心筋 imaging 行った. 撮影方向は前後, 左前斜位 $30^{\circ}$, $45^{\circ}, 60^{\circ}$ および左側面の 5 方向でNOVA-Scintipac 1,200 computer および polaroid に収録した。得られたcomputer 画像を 1 方向汇つき 3 ケ所，合計 15 対の segment に分画し，安静時，運動負荷中のそれぞれ同一部位にお ける放射活性を，関心領域を設定して測定し，心筋局所 灌流比 (SPR, 既報) を計算し, 冠血管病変の存在診断, 部位骖断を行った。また，心機能を評洒する目的で一部 の症例では $99 \mathrm{~m}$ Tc-HSA による Cardiac pool image の computer 解析を行い, 心拍出量, 歌出分劃, 左室拡張 終期容積, 左室収縮周期 Profil などの検討を加えた。

成績；健常例では心筋各所引負荷に伴い，注ぼ均等な 增加率で灌流され，SPR は $1.01 \pm 0.1$ である. 一方, 冠 動脈写により病変が確認され，かつ負荷で狭心発作誘発

Japanese Circulation Journal Vol. 43, March $x 979$ 